Bài báo khoa học

\title{
Mô phỏng xâm nhập mặn các sông chính trên địa bàn tỉnh Bà Rịa - Vũng Tàu trong bối cảnh biến đổi khí hậu
}

\author{
Nguyễn Văn Hồng ${ }^{*}$, Nguyễn Phương Đông ${ }^{1}$ \\ ${ }^{1}$ Phân Viện Khoa học Khí tượng Thủy văn và Biến đổi khí hậu; \\ nguyenvanhong79@gmail.com; donghai930t110@gmail.com
}

*Tác giả liên hệ: nguyenvanhong79@gmail.com; Tel.: +84-913613206

Ban Biên tập nhận bài: 8/4/2021; Ngày phản biện xong: 16/6/2021; Ngày đăng bài: $25 / 8 / 2021$

Tóm tắt: Bài báo này tập trung mô phỏng nguy cơ xâm nhập mặn các sông chính trên địa bàn tỉnh Bà Rịa-Vũng Tàu giai đoạn đến năm 2050 theo các kịch bản biến đổi khí hậu RCP4.5 và RCP8.5. Trong nghiên cứu, sử dụng mô hình MIKE với module MIKE NAM để tính toán dòng chảy từ mưa, làm điều kiện đầu vào mô hình MIKE 11, tiếp tục mô phỏng thủy lực và xâm nhập mặn. Kết quả tính toán từ mô hình cho thấy mặn xâm nhập chủ yếu ở các huyện phía Nam, phân bố dọc theo sông Ray, sông Cỏ Mây và sông Dinh gần về phía hạ lưu. Trong khi đó, trên sông Thị Vải, ranh mặn này vượt qua ranh giới tỉnh khoảng 2,7 $\mathrm{km}$ và $5,7 \mathrm{~km}$ tương ứng với $\mathrm{RCP} 4.5$ và $\mathrm{RCP} 8.5$. Độ mặn cao nhất trên sông Dinh, đoạn chảy qua huyện Long Điền và thành phố Vũng Tàu không lớn $(<1 \%$ ), theo đó, biên độ dao động mặn không đáng kể. Huyện Tân Thành là khu vực đáng quan tâm nhất trong mối quan hệ với xâm nhập mặn, chiếm $68 \%$ diện tích phơi nhiễm với xâm nhập mặn cả tỉnh (> 1\%o).

Từ khóa: Xâm nhập mặn, sông, Biến đổi khí hậu, Nước biển dâng, Kịch bản.

\section{Mở đầu}

Xâm nhập mặn (XNM) là hiện tượng tự nhiên xảy ra ở các vùng đất, cửa sông, tầng chứa nước tiếp giáp với biển; với độ mặn thay đổi tùy thuộc vào quá trình tự nhiên như chế độ thủy triều, dòng chảy của sông và địa hình hay hoạt động của con người gây ra như thay đồi hiện trạng sử dụng đất. Tuy nhiên, trong bối cảnh biến đổi khí hậu $(\mathrm{BĐKH)} \mathrm{ngày} \mathrm{càng} \mathrm{phức}$ tạp và gia tăng về quy mô, diễn biến và tần suất đã ảnh hưởng nhiều đến chu trình thủy văn thông qua thay đổi lượng mưa, lượng nước bốc hơi, mực nước biển dâng (NBD); từ đó làm thay đổi tốc độ bổ sung nguồn nước ngầm cho các hệ thống tầng ngậm nước, gây ảnh hưởng đến quá trình $\mathrm{XNM}$. Vì vậy, các tác động của $\mathrm{BĐKH}$ đến quá trình thủy văn và tài nguyên nước ở địa phương hoặc khu vực cần được đẩy mạnh, quan tâm hơn [1-5].

Bà Rịa-Vũng Tàu là một tỉnh ven biển thuộc vùng Đông Nam Bộ, trong những năm qua tỉnh đã và đang phải hứng chịu hậu quả của tác động của $\mathrm{BĐKH}$, trong đó vấn đề XNM xảy ra ở nhiều khu vực ven biển và đang lấn sâu vào trong nội đồng gây ảnh hưởng không nhỏ đến môi trường, hoạt động sản xuất và sinh hoạt của người dân, nhiều nơi diện tích phải bỏ hoang do ruộng đồng bị nhiễm mặn nghiêm trọng. Mặc dù đã xảy ra nhiều thiệt hại đáng kể đối với sản xuất nông nghiệp và nguồn cung cấp nước ngọt, nhưng các đánh giá định lượng về dòng chảy và quá trình nhiễm mặn trong tương lai vẫn còn nhiều hạn chế do thiếu dữ liệu quan trắc và công cụ mô hình để đại diện cho một mạng lưới thủy lực phức tạp. Do đó, làm rõ thực trạng XNM cũng như đánh giá, dự báo trong tương lai để hỗ trợ trong việc đưa ra 
quyết định và các giải pháp thích ứng phù hợp cần được tiến hành thực hiện trên địa bàn tỉnh Bà Rịa-Vũng Tàu [5-10].

Với mục đích nghiên cứu XNM các sông chính trên địa bàn tỉnh Bà Rịa-Vũng Tàu, nghiên cứu đã sử dụng phương pháp mô hình toán, cụ thể là phần mềm MIKE (DHI) với module MIKE NAM tính toán dòng chảy đến và lưu lượng nhập biên của các lưu vực, tiểu lưu vực vào mô hình MIKE 11 mô phỏng XNM. Bên cạnh đó, các kịch bản $\mathrm{BĐKH}$ và NBD cho khu vực tỉnh Bà Rịa-Vũng Tàu cũng được tính toán cùng với hiện tượng $\mathrm{XNM}$, gồm kịch bản RCP 4.5, kịch bản RCP 8.5 với mực nước năm 2020, 2030, 2050 tăng so với kịch bản hiện trạng. Ngoài ra, phần mềm ArcGIS được sử dụng để xử lý số liệu đầu vào, phân tích độ mặn cho khu vực nghiên cứu từ kết quả tính toán thủy lực và biểu diễn lên bản đồ [1120].

\section{Phương pháp nghiên cứu}

\subsection{Khu vục nghiên cứu}

Bà Rịa-Vũng Tàu là tỉnh thuộc vùng Đông Nam Bộ, nằm trong vùng trọng điểm kinh tế phía Nam. Địa giới hành chính gồm phần đất liền và hải đảo, chia thành 05 huyện $(01$ huyện đảo), 02 thành phố và 01 thị xã. Với chiều dài 16,33 km giáp thành phố Hồ Chí Minh ở phía Tây; 116,5 km giáp Đồng Nai ở phía Bắc; 29,26 km giáp Bình Thuận ở phía Đông, Nam và Tây Nam giáp biển Đông. Chiều dài bờ biển là $305,4 \mathrm{~km}$ với trên $100.000 \mathrm{~km}^{2}$ thềm lục địa.

Biên độ nhiệt độ ngày và năm nhỏ, nhiệt độ bình quân giữa các mùa không chênh lệch lớn. Nhiệt độ bình quân các tháng dao động từ $25,5^{\circ} \mathrm{C}$ đến $28,9^{\circ} \mathrm{C}$. Lượng mưa trong năm nhìn chung thuộc loại nhỏ so với các vùng ở miền Đông Nam Bộ, trung bình năm khoảng $1.500-1.600 \mathrm{~mm}$.

Ngoài ra, tỉnh có hệ thống sông suối rất đa dạng, gồm 4 hệ thống sông chính là sông Thị Vải, sông Dinh, sông Ray và sông Đu Đủ. Về hệ thống các hồ, tỉnh hiện có khoảng 30 hồ chứa nước quy mô trung bình và nhỏ, các hồ này có chức năng cấp nước nông nghiệp, sinh hoạt và công nghiệp, dịch vụ [4-5].

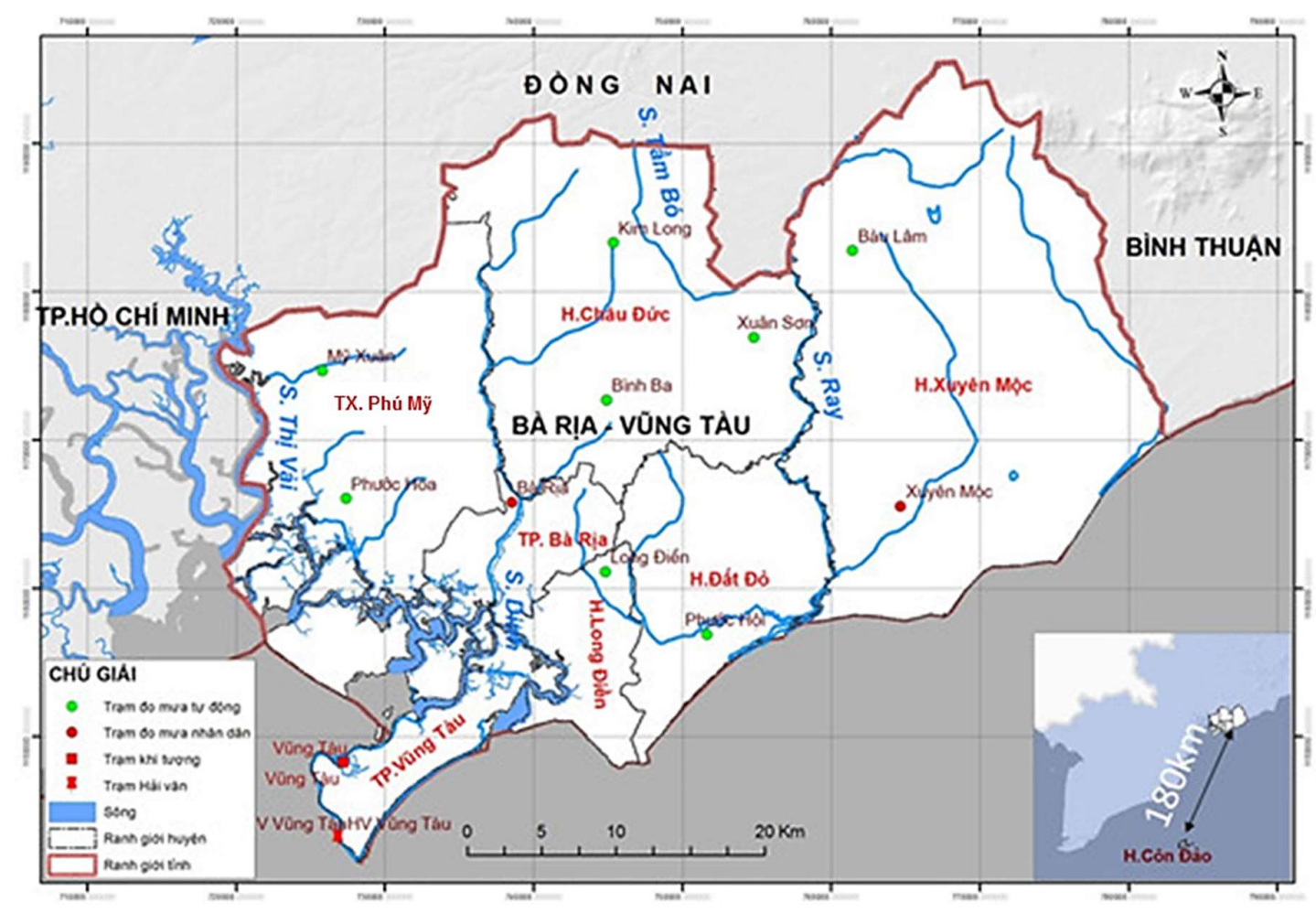

Hình 1. Bản đồ vị trí các trạm Khí tượng Thủy văn tỉnh Bà Rịa-Vũng Tàu. 
Bảng 1. Danh sách trạm khí tượng thủy văn tỉnh Bà Rịa - Vũng Tàu.

\begin{tabular}{|c|c|c|c|c|}
\hline Loại trạm & Tên Trạm & Địa danh & Kinh độ & Vĩ độ \\
\hline \multirow[t]{2}{*}{ Khí tượng } & Vũng Tàu & $\begin{array}{c}\text { Số } 278 \text { Nguyễn An Ninh - TP Vũng } \\
\text { Tàu }\end{array}$ & $107^{\circ} 5^{\prime} 00^{\prime \prime}$ & $10^{\circ} 22^{\prime} 03^{\prime \prime}$ \\
\hline & Côn Đảo & Số 7 Nguyễn Huệ, Huyện Côn Đảo & $106^{\circ} 36^{\prime} 22^{\prime \prime}$ & $08^{\circ} 41^{\prime} 02^{\prime \prime}$ \\
\hline \multirow[t]{2}{*}{ Hải văn } & Vũng Tàu & $\begin{array}{c}\text { Số } 278 \text { Nguyễn An Ninh - TP Vũng } \\
\text { Tàu }\end{array}$ & $107^{\circ} 04^{\prime} 16^{\prime \prime}$ & $10^{\circ} 20^{\prime} 22^{\prime \prime}$ \\
\hline & Côn Đảo & Số 7 Nguyễn Huệ, Huyện Côn Đảo & $106^{\circ} 36^{\prime} 34^{\prime \prime}$ & $08^{\circ} 40^{\prime} 51^{\prime \prime}$ \\
\hline \multirow{2}{*}{$\begin{array}{l}\text { Đo mưa nhân } \\
\text { dân }\end{array}$} & Bà Rịa & $\begin{array}{c}\text { Phường Phước Nguyên, Thành phố Bà } \\
\text { Rịa }\end{array}$ & $107^{\circ} 10^{\prime} 33^{\prime \prime}$ & $10^{\circ} 32^{\prime} 47^{\prime \prime}$ \\
\hline & Xuyên Mộc & $\begin{array}{c}\text { Phước Bửu (Thị Trấn), Huyện Xuyên } \\
\text { Mộc }\end{array}$ & $107^{\circ} 24^{\prime} 56^{\prime \prime}$ & $10^{\circ} 32^{\prime} 49^{\prime \prime}$ \\
\hline \multirow{7}{*}{ Đo mưa tự động } & Mỹ Xuân & Mỹ Xuân, Tx. Phú Mỹ & $107^{\circ} 03^{\prime} 14^{\prime \prime}$ & $10^{\circ} 37^{\prime} 21^{\prime \prime}$ \\
\hline & Phước Hoà & Phước Hòa, Tx. Phú Mỹ & $107^{\circ} 04^{\prime} 19^{\prime \prime}$ & $10^{\circ} 32^{\prime} 33^{\prime \prime}$ \\
\hline & Long Điền & Trị trấn Long Điền & $107^{\circ} 13^{\prime} 15^{\prime \prime}$ & $10^{\circ} 29^{\prime} 32^{\prime \prime}$ \\
\hline & Kim Long & Huyện Châu Đức & $107^{\circ} 14^{\prime} 39^{\prime \prime}$ & $10^{\circ} 42^{\prime} 09^{\prime \prime}$ \\
\hline & Bàu Lâm & Bàu Lâm, Xuyên Mộc & $107^{\circ} 23^{\prime} 20^{\prime \prime}$ & $10^{\circ} 41^{\prime} 09^{\prime \prime}$ \\
\hline & Phước Hội & Phước Hội, Đất Đỏ & $107^{\circ} 16^{\prime} 56^{\prime \prime}$ & $10^{\circ} 27^{\prime} 02^{\prime \prime}$ \\
\hline & Xuân Sơn & Huyện Châu Đức & $107^{\circ} 19^{\prime} 45^{\prime \prime}$ & $10^{\circ} 38^{\prime} 51^{\prime \prime}$ \\
\hline
\end{tabular}

\subsection{Dũ liệu tính toán}

\subsubsection{Dữ liệu địa hình, mặt cắt ngang}

- Bản đồ địa hình tỉnh Bà Rịa-Vũng Tàu: miền tính được thiết lập trong hệ tọa độ UTM 48 với 60090 phần tử và 30623 nút.

- Dữ liệu mặt cắt: được dẫn cao độ chuẩn Quốc gia và xác định vị trí trên bản độ địa hình tỉ lệ $1 / 10.000$ để làm cơ sở xác định vị trí mặt cắt sông trên sơ đồ thủy lực (lòng sông Thị Vải, sông Dinh, sông Cỏ Mây, sông Ray và hệ thống kênh rạch sông Sài Gòn-Đồng Nai) chủ yếu do Tổng cục Khí tượng Thuỷ văn cũ (nay là Bộ Tài nguyên và Môi trường) đo đạc, ngoài ra còn được cập nhật, bổ sung, kế thừa từ các đề tài, dự án đã thực hiện tại khu vực nghiên cứu.

\subsubsection{Dữ liệu khí tượng thủy văn}

Các dữ liệu phục vụ quá trình thiết lập và hiệu chỉnh-kiểm định mô hình MIKE NAM, MIKE 11 được thu thập tại Đài khí tượng Thủy văn khu vực Nam Bộ năm 2017 và 2018, gồm:

- Số liệu mưa: chuỗi giá trị thực đo trung bình theo ngày trạm Tà Lài, Xuyên Mộc, Trị An và Bà Rịa.

- Số liệu bốc hơi: chuỗi giá trị thực đo trung bình theo ngày trạm Trị An.

- Số liệu lưu lượng: chuỗi giá trị thực đo trung bình theo ngày xả hồ Trị An và một phần lưu lượng từ sông Bé và sông Sài Gòn để tính toán lưu lượng đến và lưu lượng nhập bên cho lưu vực nghiên cứu.

- Số liệu mực nước: Chuỗi giá trị thực đo theo giờ tại trạm thủy văn Phú An và Trạm hải văn Bà Rịa-Vũng Tàu. 


\subsection{Thiết lập mô hình}

\subsubsection{Mô hình tính toán dòng chảy từ mưa (MIKE NAM)}

Để tính toán dòng chảy đến các tiểu lưu vực và lưu lượng nhập bên cho các nhánh sông làm biên đầu vào mô hình MIKE 11, dữ liệu thiết lập mô hình NAM gồm:

- Các lưu vực sông được phân định thành các tiểu lưu vực theo hệ thống hồ chứa thủy lợi và các trạm đo lưu lượng (Hình 2). Các lưu vực được xác định ranh giới trên cơ sở dữ liệu cao độ số (DEM 12,5×12,5 m).

- Sử dụng số liệu mưa của trạm Tà Lài, Xuyên Mộc, Trị An và Bà Rịa; số liệu bốc hơi và lưu lượng về hồ Trị An. Trọng số mưa cho từng tiểu lưu vực được tính bằng đa giác Thiesen.

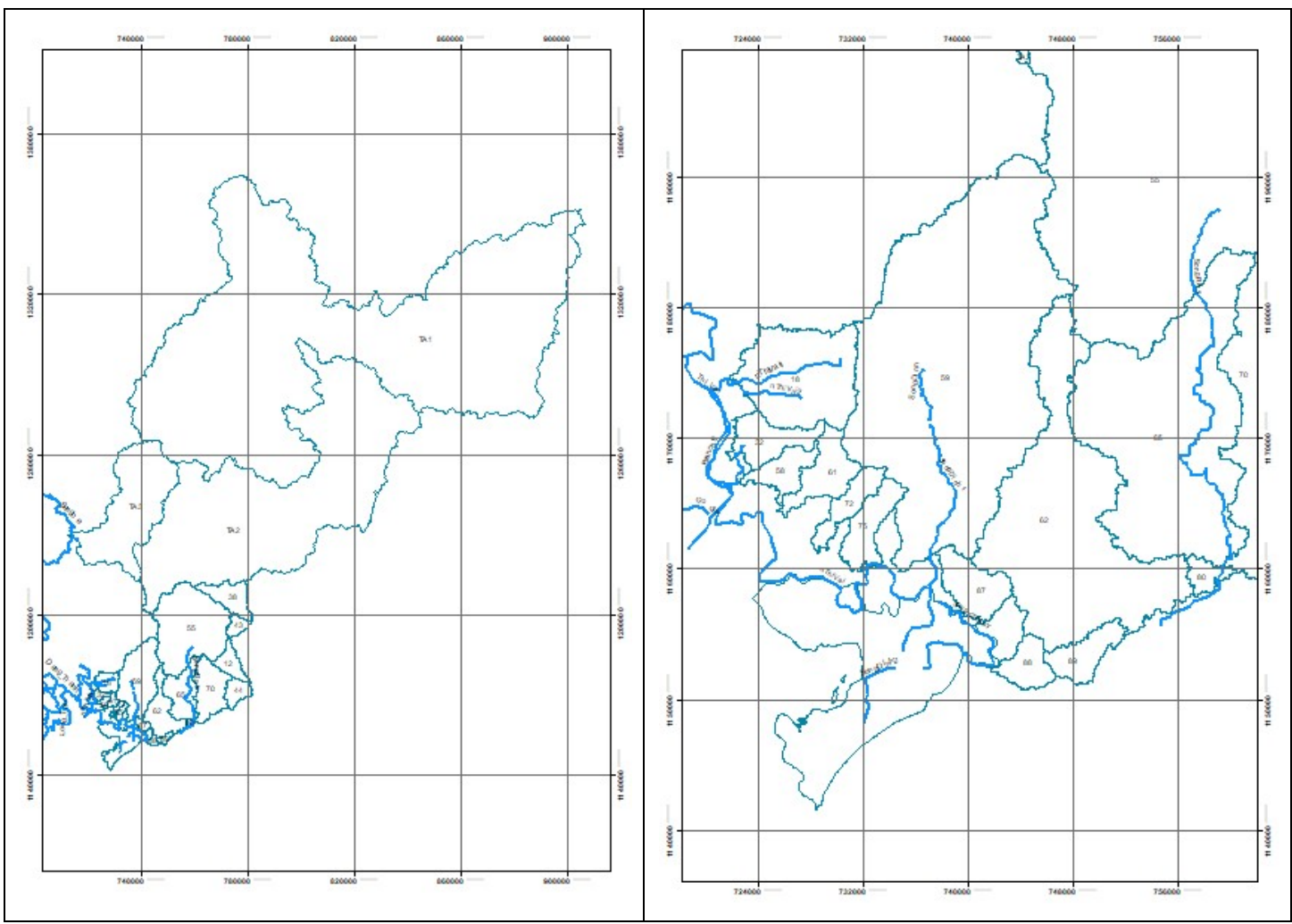

Hình 2. Kết quả phân chia các lưu vực và các tiểu lưu vực sông vùng nghiên cứu trong MIKE NAM.

\subsubsection{Mô hình MIKE $11 \mathrm{HD}$ và $\mathrm{AD}$}

- Mạng lưới sông: số hóa bằng phần mềm ArcGis 10.1 trên nền bản đồ địa hình tỷ lệ 1/10.000, sau đó nhập vào mô hình MIKE 11. Các mặt cắt và mạng lưới sông được nối với nhau bằng mã liên kết; gồm 273 mặt cắt trên toàn hệ thống sông Dinh, sông Ray, sông Thị Vải, sông Cỏ Mây và một số nhánh nhỏ khác (Hình 3). Ngoài ra, sông Thị Vải còn được kết nối với hệ thống sông Sài Gòn-Đồng Nai để hiệu chỉnh, kiểm định cả mạng dữ liệu lớn (Hình 4).

- Dũ̃ liệu tính toán thủy văn gồm:

+ Biên thượng nguồn: Lưu lượng nhập biên vào sông Dinh, sông Ray, sông Thị Vải và sông Cỏ Mây, sinh ra từ mưa đến các tiểu lưu vực sau khi đã hiệu chỉnh ở MIKE NAM, sẽ được kết nối vào mô hình MIKE 11 làm lưu lượng nhập biên cho mô hình thủy lực.

+ Biên hạ nguồn: Mực nước trạm hải văn Vũng Tàu.

- Số liệu tính toán lan truyền mặn: mức độ truyền tải khuếch tán 2-500, độ mặn các biên thượng nguồn là 0 PSU, biên hạ nguồn là 25-28 PSU. 
- Quá trình thiết lập mô hình mô phỏng nguy cơ XNM trên các sông chính chảy qua tỉnh Bà Rịa-Vũng Tàu được thể hiện trong Hình 5.

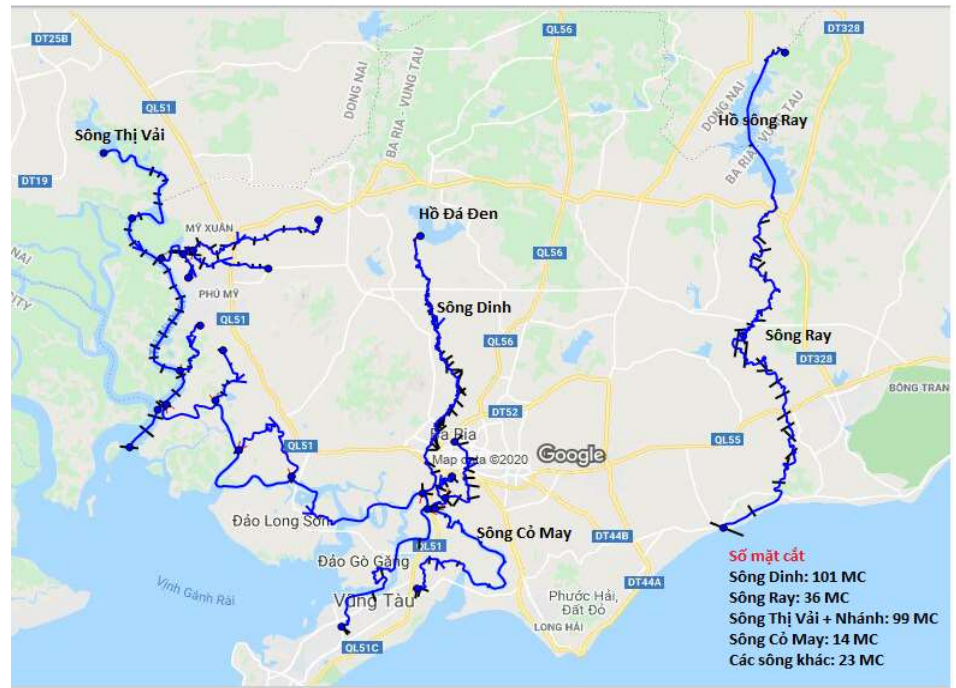

Hình 3. Sơ đồ mặt cắt thủy lực trên hệ thống sông tỉnh Bà Rịa-Vũng Tàu.

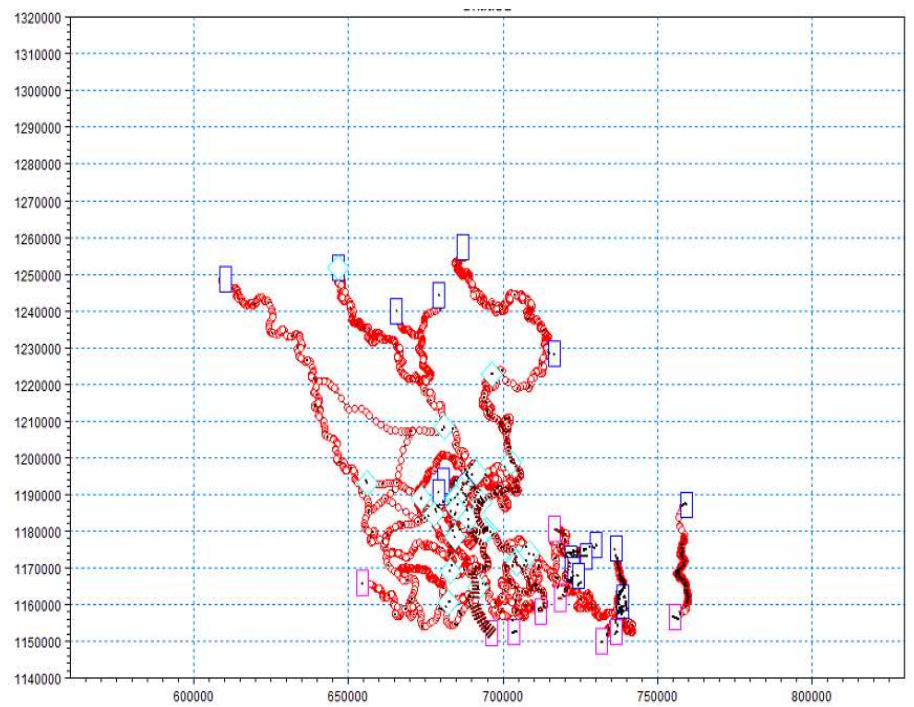

Hình 4. Kết nối nhập biên mô hình mưa-dòng chảy vào mô hình thủy lực MIKE 11. 


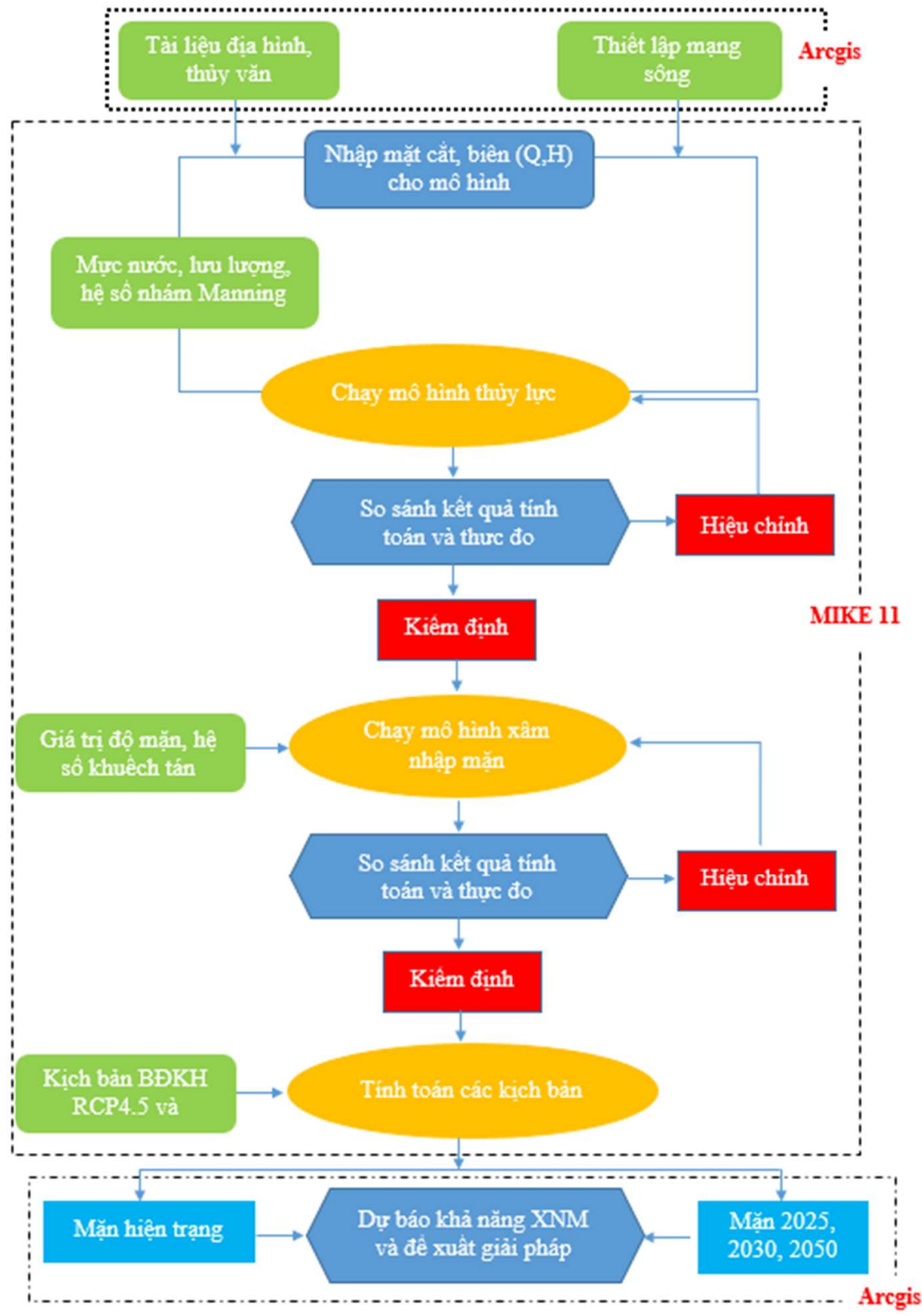

Hình 5. Quy trình thiết lập mô hình MIKE mô phỏng xâm nhập mặn.

\subsection{Các kịch bản tính toán}

Các kịch bản $\mathrm{BĐKH} \mathrm{và} \mathrm{NBD} \mathrm{cho} \mathrm{khu} \mathrm{vực} \mathrm{tỉnh} \mathrm{Bà} \mathrm{Rịa-Vũng} \mathrm{Tàu} \mathrm{được} \mathrm{tính} \mathrm{toán} \mathrm{theo}$ hướng dẫn của IPCC trong báo cáo AR5 bằng phần mềm Mike Zero Climate Change, các kịch bản được áp dụng để tính toán như sau:

+ Kịch bản RCP 4.5: Lượng mưa mùa khô theo kịch bản BĐKH vào năm 2025 biến đổi $16,5 \%$, năm 2030 biến đổi $16,5 \%$, tiếp tục biến đổi dương $5,2 \%$ vào năm 2050 so với thời kỳ nền (1986-2005). Nhiệt độ vào năm 2025 biến đổi $0,8^{\circ} \mathrm{C}$, năm 2030 tăng $0,8^{\circ} \mathrm{C}$, năm 2050 tăng $1,3^{\circ} \mathrm{C}$. Mực nước năm 2025, 2030, 2050 tăng tương ứng $10 \mathrm{~cm}, 12 \mathrm{~cm}, 21 \mathrm{~cm}$ so với giai đoạn nền (1986-2005).

+ Kịch bản RCP 8.5: Lượng mưa giai đoạn đầu thế kỷ vào năm 2025 biến đổi dương là $8,7 \%$, năm 2030 biến đổi $8,7 \%$, đến năm 2050 lượng mưa biến đổi $7,3 \%$. Nhiệt độ tăng $0,8^{\circ} \mathrm{C}$ vào năm 2025 , năm 2030 tăng $0,8^{\circ} \mathrm{C}$ và vào năm 2050 tăng $1,8^{\circ} \mathrm{C}$. Mực nước năm 2020 , 2030, 2050 tăng tương ứng $10 \mathrm{~cm}, 12 \mathrm{~cm}, 25 \mathrm{~cm}$ so với giai đoạn nền (1986-2005). 


\section{Kết quả và thảo luận}

\subsection{Kết quả hiệu chỉnh và kiểm định mô mưa dòng chảy NAM}

Mô hình được hiệu chỉnh dựa vào lưu lượng thực đo tại trạm Trị An từ 01/01/2017 đến $31 / 12 / 2017$. Đánh giá mức độ tin cậy của mô hình theo hệ số tương quan $\mathrm{R}^{2}$ cho thấy mức độ phù hợp giữa giá trị thực đo so với giá trị mô phỏng là 0,801 (đạt loại tốt). Đường quá trình lưu lượng tính từ mưa khá phù hợp với đường quá trình dòng chảy thực đo (Hình 5 ). Qua đó có thể dùng các thông số trong mô hình để hoàn nguyên dòng chảy trong quá khứ và có thể đánh giá được chế độ dòng chảy, lượng nước đến tại khu vực nghiên cứu phục vụ tính toán thủy lực, cũng như tính toán các kịch bản biến đổi khí hậu trong tương lai.

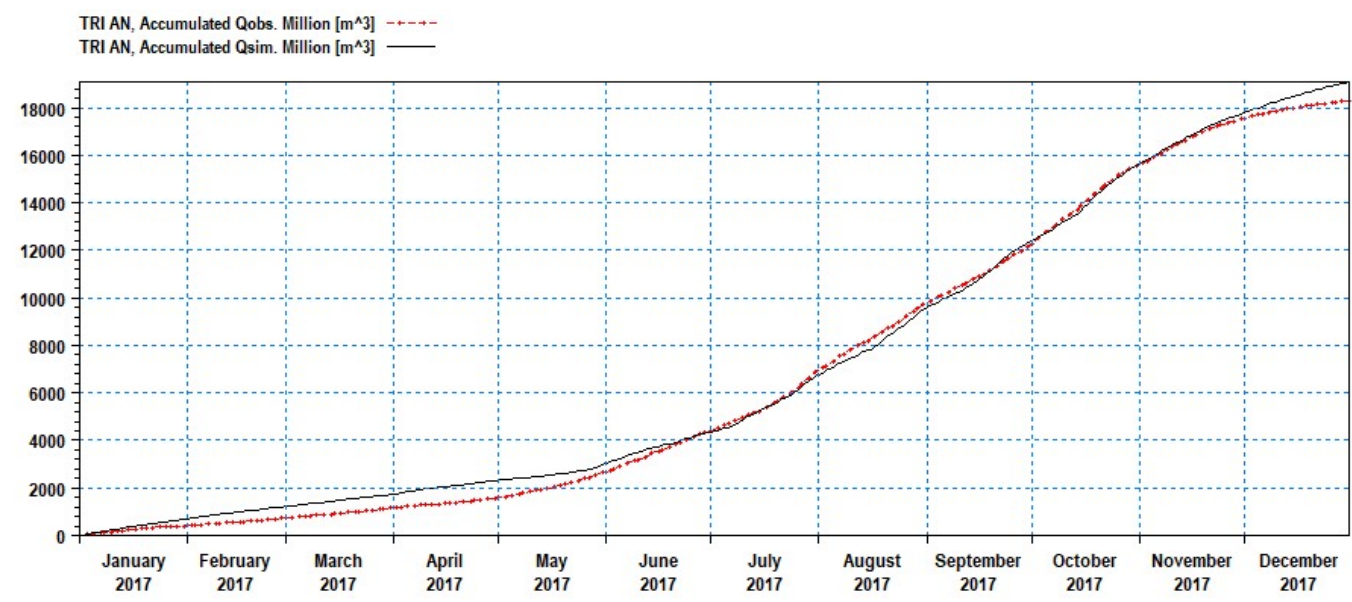

Hình 5. Hiệu chỉnh lưu lượng trạm Trị An năm 2017.

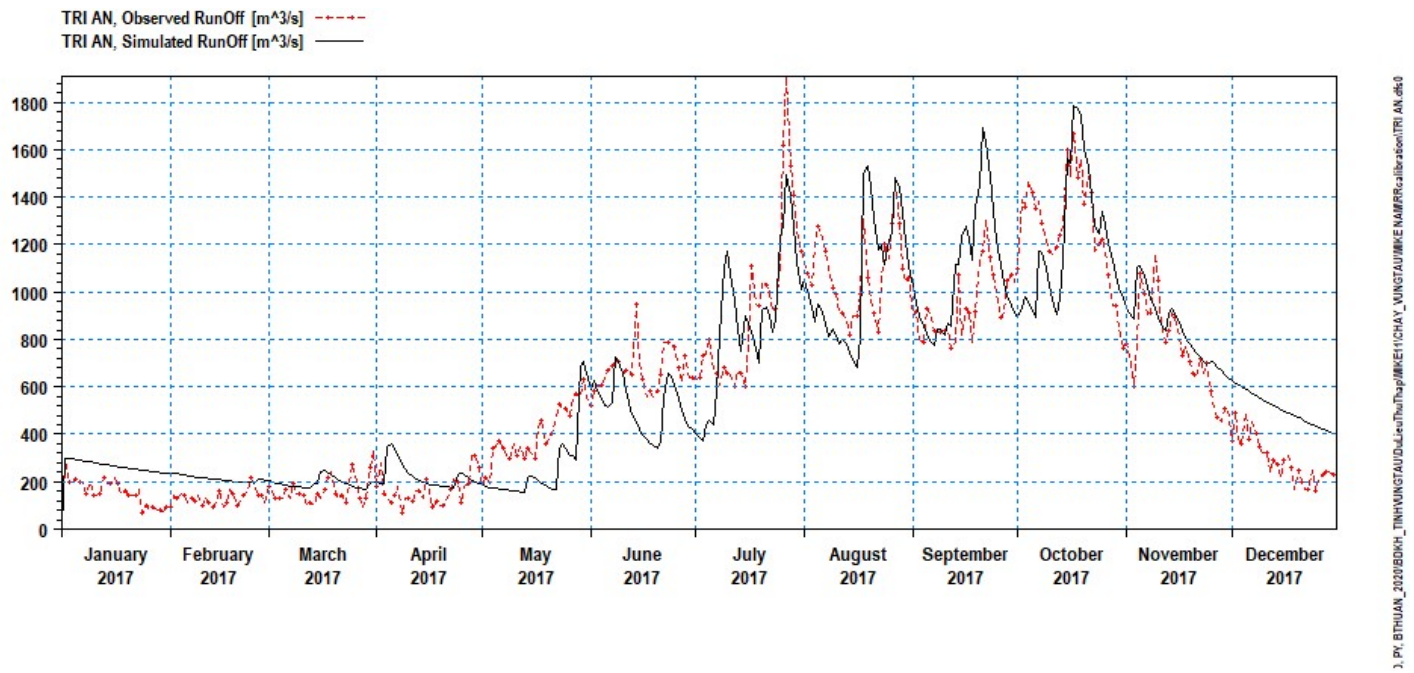

Hình 6. Hiệu chỉnh mực nước trạm Trị An năm 2017.

\subsection{Kết quả hiệu chỉnh và kiểm định mô hình MIKE 11}

- Sử dụng số liệu tại trạm Phú An từ ngày 29/3/2017 đến ngày 31/3/2017 cho quá trình hiệu chỉnh và từ ngày $1 / 3 / 2018$ đến ngày $31 / 3 / 2018$ cho quá trình kiểm định.

- Bước thời gian tính toán thủy lực: $\Delta \mathrm{t}=5$ phút.

- Điều kiện ban đầu: mực nước $\mathrm{H}=1.0 \mathrm{~m}$, lưu lượng $\mathrm{Q}=0 \mathrm{~m}^{3} / \mathrm{s}$.

- Hệ số Manning's M: thay đổi theo độ sâu từ 20-60 (m³/s/s) phụ thuộc từng đoạn sông. 


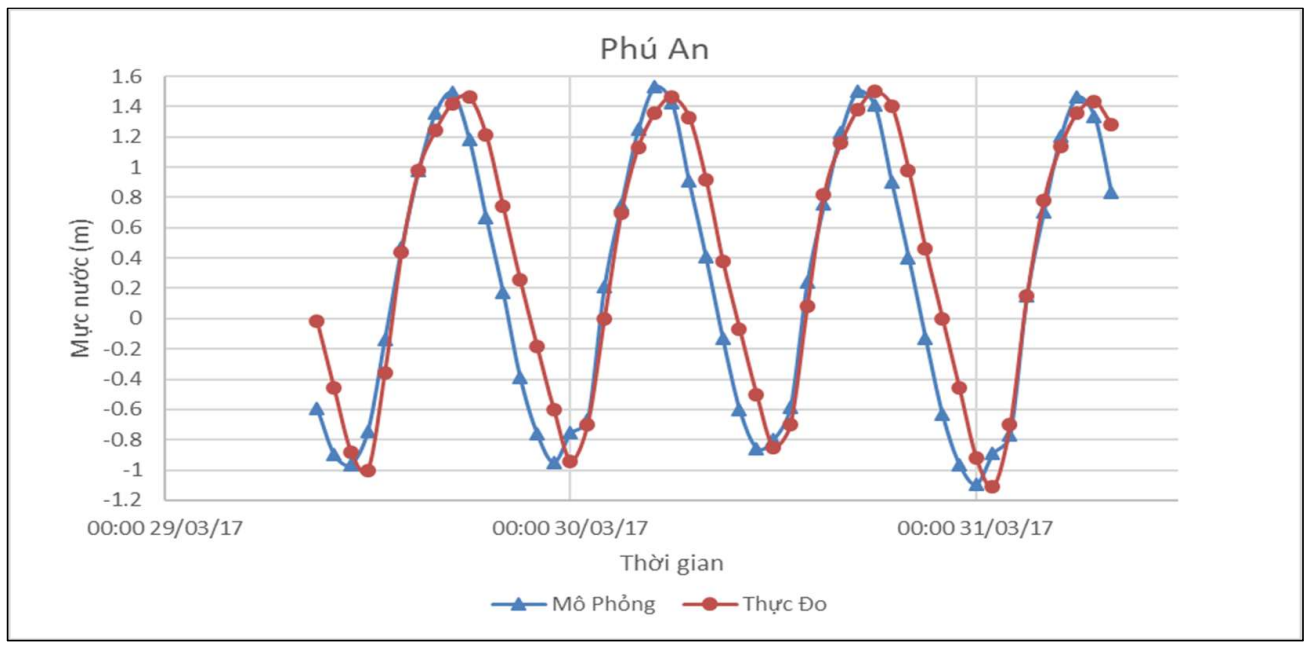

Hình 7. Hiệu chỉnh mực nước trạm Phú An năm 2017.

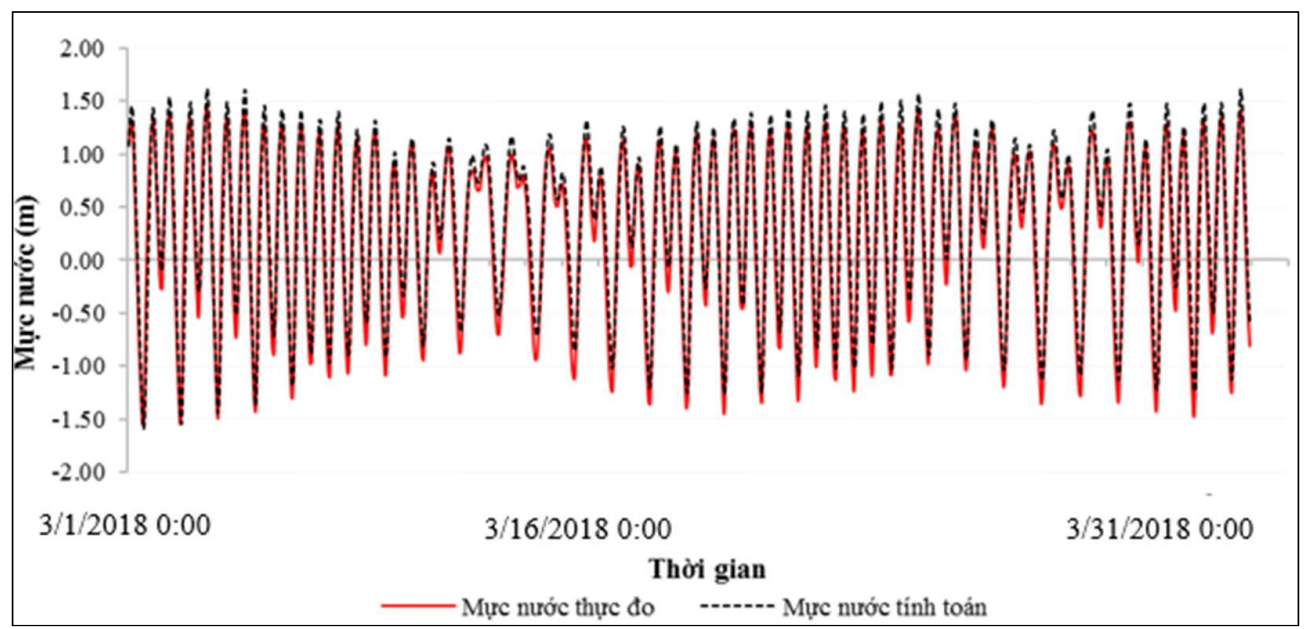

Hình 8. Kiểm định mực nước trạm Phú An năm 2018.

Kết quả hiệu chỉnh-kiểm định giữa mực nước thực đo và tính toán tại trạm Phú An qua hệ số tương quan $\mathrm{R}^{2}$ lần lượt là 0,86 và 0,97 (đạt loại tốt), cho thấy bộ thông số mô hình là phù hợp, đảm bảo độ tin cậy để mô phỏng các kịch bản XNM.

\subsection{Kết quả mô phỏng các kịch bản xâm nhập mặn}

Thời gian mô phỏng XNM: từ tháng 3 đến tháng 4 năm 2018, thời điểm mực nước thấp trên các sông nội tỉnh Bà Rịa-Vũng Tàu và hệ thống sông Sài Gòn-Đồng Nai; hạn hán và $\mathrm{XNM}$ đi vào thời gian cao điểm trong năm.

Mô phỏng XNM theo các kịch bản BĐKH tại khu vực nghiên cứu, tiến hành tính toán mức độ tăng giảm của lượng mưa và nhiệt độ chạy lại mô hình, sau đó xuất kết quả lưu lượng đến các tiểu lưu vực và lưu lượng nhập biên theo các kịch bản để làm biên đầu vào cho mô hình thủy lực.

Kết quả mô phỏng độ mặn và diện tích nhiễm mặn trên các sông chính tỉnh Bà Rịa-Vũng Tàu theo kịch bản hiện trạng (năm 2018) và các kịch bản NBD RCP4.5, RCP8.5 (năm 2025, 2030, 2050) được trình bày lần lượt từ Hình 7 đến Hình 10 và trong Bảng 2; Ngoài ra các kịch bản thủy văn được tính toán từ module $\mathrm{CC}$ trong Mike Nam dựa vào năm hiện trạng. 


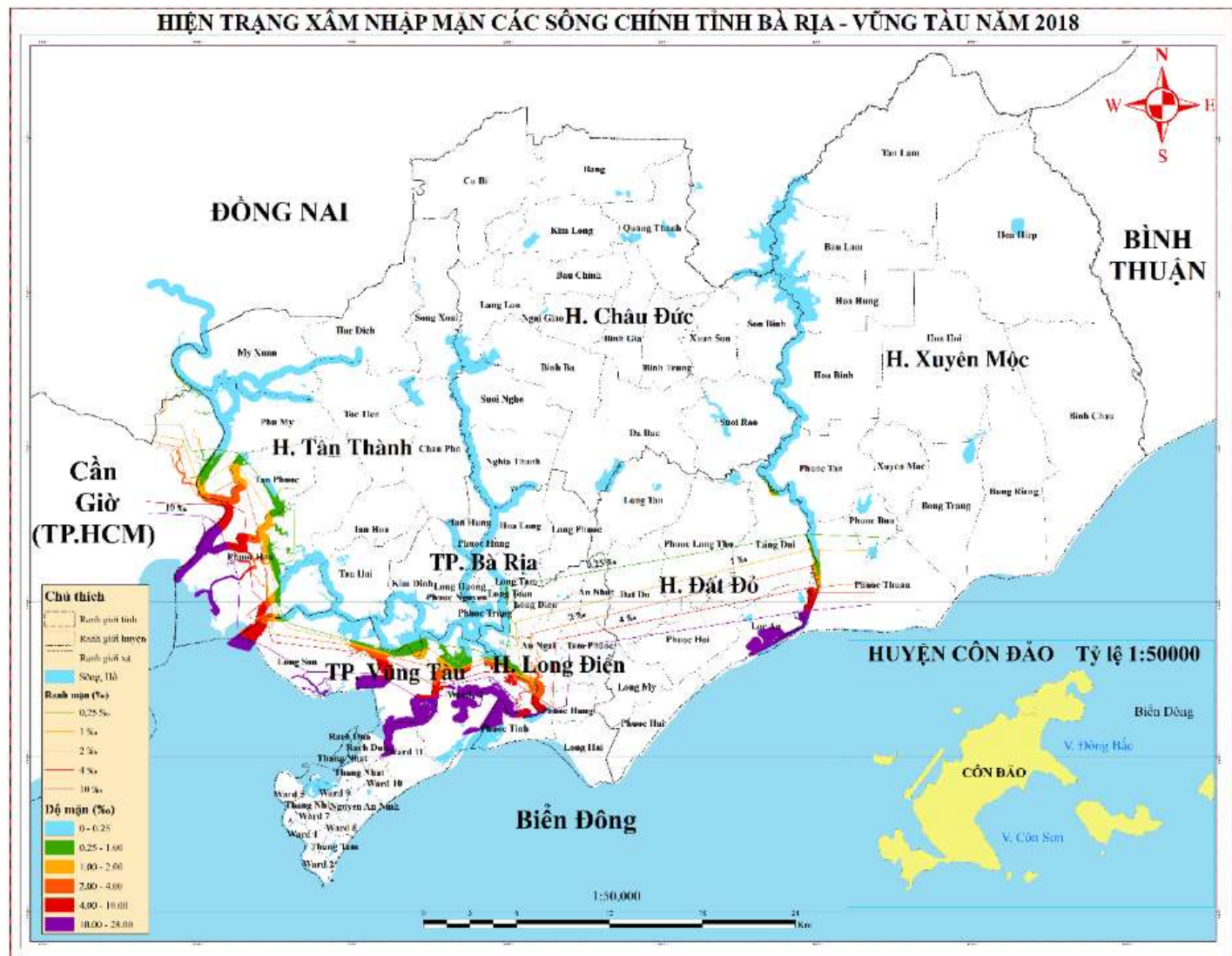

Hình 7. Bản đồ hiện trạng xâm nhập mặn trên các sông chính tỉnh Bà Rịa-Vũng Tàu tháng 3/2018.

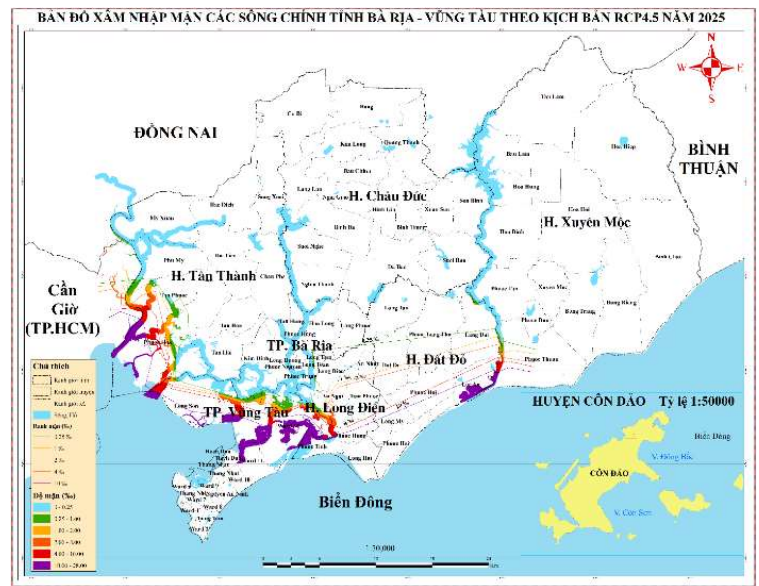

(a)

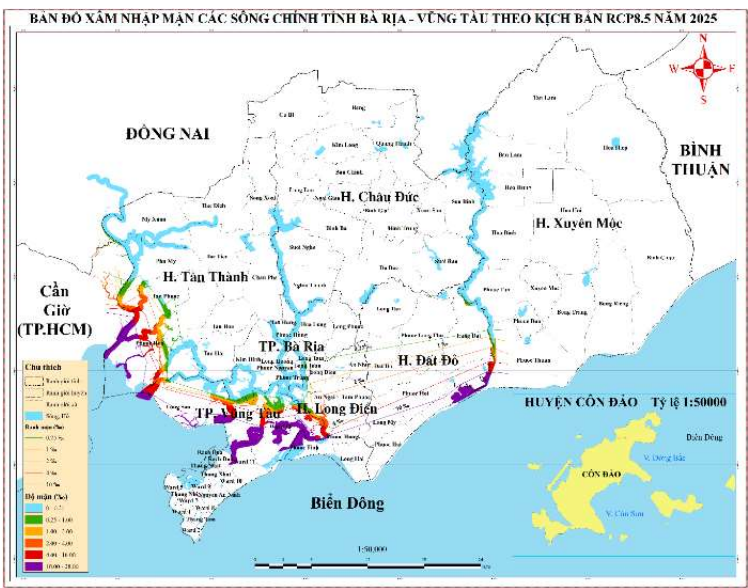

(b)

Hình 8. Độ mặn cao nhất trên các sông chính tỉnh Bà Rịa-Vũng Tàu năm 2025 theo kịch bản RCP4.5 (a) và $\mathrm{RCP} 8.5$ (b). 


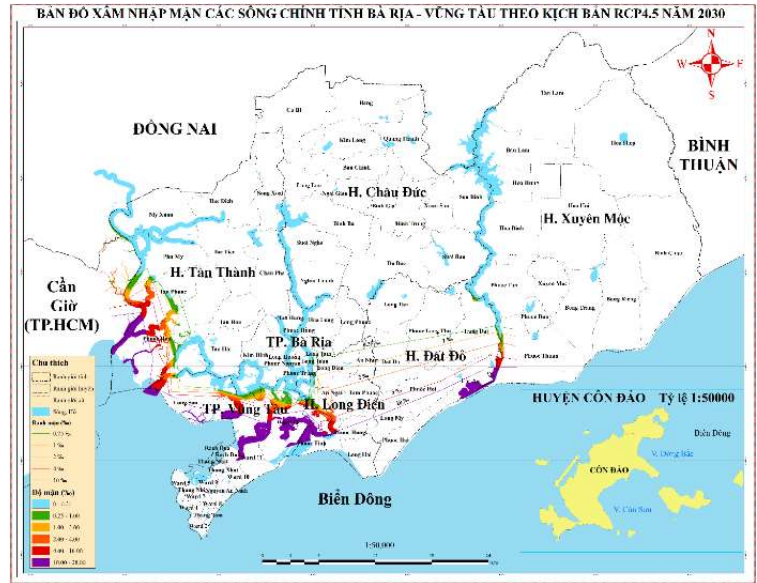

(a)

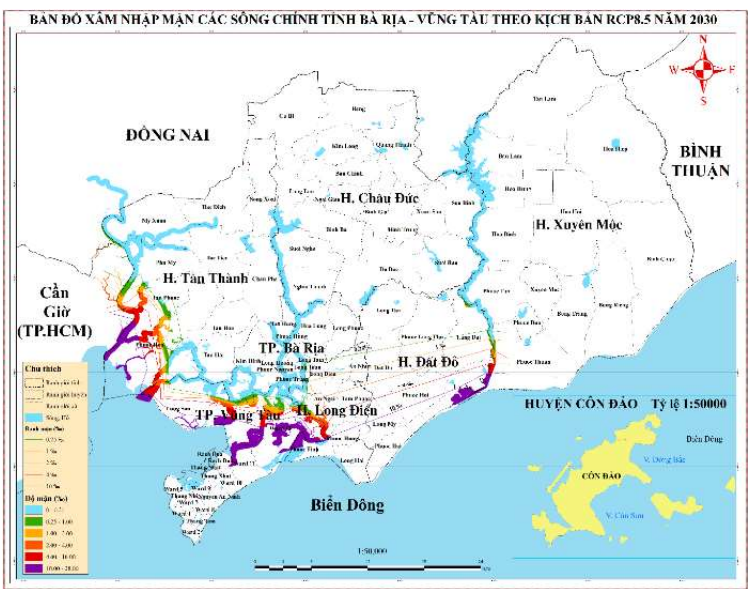

(b)

Hình 9. Độ mặn cao nhất trên các sông chính tỉnh Bà Rịa-Vũng Tàu năm 2030 theo kịch bản RCP4.5 (a) và RCP8.5 (b).

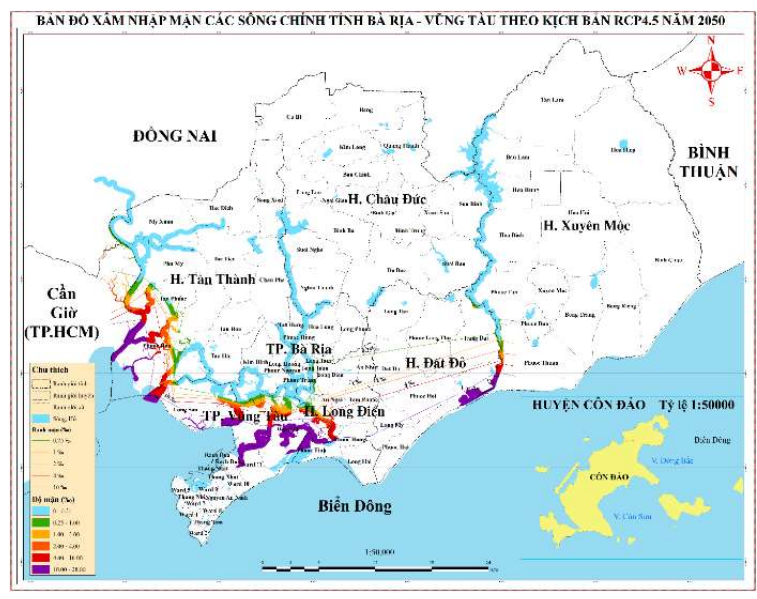

(a)

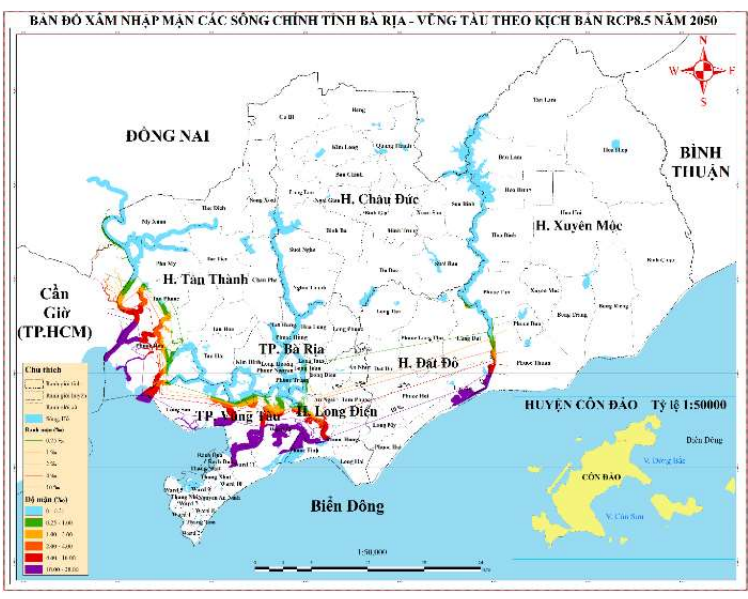

(b)

Hình 10. Độ mặn cao nhất trên các sông chính tỉnh Bà Rịa-Vũng Tàu năm 2050 theo kịch bản RCP4.5 (a) và RCP8.5 (b).

Bảng 2. Kết quả diện tích phơi nhiễm mặn trên các sông chính tại Bà Rịa-Vũng Tàu theo ranh mặn trên 1\%o.

\begin{tabular}{|c|c|c|c|c|c|c|c|}
\hline & $\begin{array}{c}\text { Thang mặn } \\
\text { (\%o) }\end{array}$ & $1-2$ & $2-4$ & $4-10$ & $10-28$ & $>28$ & $\begin{array}{c}\text { Tổng cộng } \\
(>1 \%)\end{array}$ \\
\hline \multirow{7}{*}{$\begin{array}{l}\text { Kịch } \\
\text { bản }\end{array}$} & S_HT & $6,341,950$ & $6,440,075$ & $8,612,400$ & $22,205,350$ & 41,425 & $43,641,200$ \\
\hline & S_45-2025 & $6,349,025$ & $6,703,000$ & $8,527,350$ & $23,348,650$ & 80,450 & $45,008,475$ \\
\hline & S_45-2030 & $6,604,475$ & $7,259,225$ & $9,032,425$ & $23,731,900$ & 150,225 & $46,778,250$ \\
\hline & S_45-2050 & $6,735,100$ & $7,700,825$ & $9,621,150$ & $24,052,575$ & 382,150 & $48,491,800$ \\
\hline & S_85-2025 & $6,404,175$ & $6,741,700$ & $8,589,500$ & $23,391,250$ & 105,400 & $45,232,025$ \\
\hline & S_85-2030 & $6,652,325$ & $7,321,825$ & $9,089,075$ & $23,777,175$ & 176,200 & $47,016,600$ \\
\hline & S_85-2050 & $6,746,975$ & $7,763,250$ & $9,690,325$ & $24,125,925$ & 360,900 & $48,687,375$ \\
\hline
\end{tabular}

\subsection{1. Độ mặn max}

Kết quả mô phỏng nồng độ mặn đạt giá trị lớn nhất vào tháng 3/2018 trên sông Cỏ Mây và sông Thị Vải lần lượt đạt gần $3 \%$ và $11 \%$, nhưng với khoảng cách vị trí từ các điểm mặn đến Thành phố Vũng Tàu và huyện Tân Thành (Thị xã Phú Mỹ) tỉnh Bà Rịa-Vũng Tàu còn 
khá xa nên mức độ ảnh hưởng đến kinh tế - đời sống sinh hoạt nông nghiệp người dân vẫn chưa bị ảnh hưởng.

Theo kết quả mô phỏng hiện trạng so sánh với kết quả mô phỏng nồng độ mặn tăng theo mực nước biển từ 2 kịch bản mực nước dâng RCP4.5 và RCP8.5, nồng độ mặn lớn nhất theo kịch bản hiện trạng trên các sông không thay đổi đáng kể so với đầu và giữa thế kỷ XXI và có xu hướng gia tăng nhẹ từ cuối thế kỷ tại vị trí sông thị Vải ranh giới tỉnh Bà Rịa-Vũng Tàu và huyện Cần Giờ. Xét vị trí giữa TP.Vũng Tàu và Huyện Long Điền nồng độ mặn tăng dần từ hiện trạng chưa đến $1 \%$ đến cuối thế kỷ đã tăng lên gần $2 \%$.

\subsubsection{Phạm vi XNM trên các sông chính}

Do tính chất lãnh thổ trải dài dọc theo đường bờ biển, nên các sông trong khu vực chịu ảnh hưởng của tiến trình XNM. Độ mặn trên $10 \%$ xuất hiện ở hạ lưu các sông. Càng tiến dần về thượng nguồn thì độ mặn giảm dần và tiến về 0 (tương ứng với vùng nước ngọt). Với điều kiện địa hình càng gần biển càng thấp dần, các sông chảy qua địa bàn tỉnh từ khu vực địa hình cao ở thượng nguồn, chảy qua địa hình thấp ở hạ nguồn. Vậy nên trên các sông khu vực hạ nguồn và vùng địa hình thấp ở sông Thị Vải, độ mặn cao và tiến sâu vào đất liền.

Trong tương lai, ranh mặn $1 \%$ có xu hướng lấn sâu hơn theo các các sông vào nội đồng. Giữa thế kỷ XXI, ranh mặn $(\mathrm{RM}) 1 \%$ đã di chuyển vào Tp. Bà Rịa và Huyện Xuyên Mộc theo hướng sông Dinh và sông Ray. Huyện Long Điền cũng sẽ bị ảnh hưởng bởi XNM khi phạm vi mặn tiến theo sông Cỏ Mây đi sâu vào nội đồng.

Xét kịch bản RCP4.5, đến giữa thế kỷ XXI, diện tích đất có khả năng phơi nhiễm với độ mặn $\geq 1 \%$ (ranh giới ngọt-lợ) gia tăng so với 2018 , chiếm $6,7 \%$ diện tích tự nhiên cả tỉnh; trong đó, huyện Trảng Bàng là khu vực phơi nhiễm nhiều nhất.

Đối với kịch bản RCP8.5, kết quả mô phỏng cũng cho thấy mức độ diễn biến của XNM dẫn đến khả năng mở rộng phạm vi phơi nhiễm tại huyện Long Điền năm 2030 tăng lên 3,69 ha và năm 2050 tăng đến 7517 ha.

Từ kết quả mô phỏng dựa trên số liệu thực tế thu thập được và công cụ mô phỏng thủy lực, thấy được diễn biến của XNM có ảnh hưởng đến sông Thị Vải và sông Cỏ Mây, Sông Dinh và Sông Ray, nhất là vị trí cửa sông như cửa Lộc $A n$, bởi lòng sông rộng và sâu, chịu tác động mạnh của thủy triều, mang tính chất của dạng cửa sông khá điển hình.

Nhưng nhìn chung khả năng XNM tại khu vực tỉnh Bà Rịa-Vũng Tàu còn bị hạn chế bởi địa hình và vị trí tọa lạc của tỉnh, nơi chủ yếu tiếp nhận nguồn nước từ thượng nguồn và ít chịu ảnh hưởng bởi chế độ thủy triều. Bởi địa hình, địa lý của 2 con sông chính chảy qua tỉnh là sông Ray và sông Dinh mà XNM còn ở mức thấp. Sông Cỏ Mây có lòng sông sâu, lại tiếp nhận nguồn nước thượng nguồn suy yếu vào mùa khô nên bị ảnh hưởng XNM, nhưng sông Cỏ Mây có rất nhiều nhánh và kênh rạch nối với sông Dinh, do đó dòng triều truyền vào dễ bị biến dạng và giảm biên độ đáng kể. Đối với sông Thị Vải dù có độ dốc nhỏ hơn (nhỏ hơn $1 \%$ ), lòng sông lại rất sâu, ít khu chứa nước nên thủy triều truyền vào rất mạnh và sâu, đa phần sông chảy trong vùng đồng bằng bằng phẳng có độ cao từ $5-20 \mathrm{~m}$, mang sắc thái vùng sông ảnh hưởng thủy triều.

Tuy nhiên, trong điều kiện $\mathrm{BĐKH} \mathrm{còn} \mathrm{khó} \mathrm{lường,} \mathrm{có} \mathrm{thể} \mathrm{thay} \mathrm{đổi} \mathrm{theo} \mathrm{chiều} \mathrm{hướng} \mathrm{tiêu}$ cực hơn, nước thượng nguồn phụ thuộc đến lượng mưa dẫn đến suy yếu tốc độ dòng chảy đến hạ lưu vào thời kỳ mùa khô; kèm theo mực nước biển tăng đem mặn lấn sâu hơn theo các con sông vào đến nội đồng tỉnh, có thể ảnh hưởng đến ngành nông nghiệp và nguồn nước ngọt trong quá trình sinh hoạt của người dân tỉnh Bà Rịa-Vũng Tàu.

\section{Kết luận}

Nghiên cứu sử dụng mô hình MIKE NAM và MIKE 11 mô phỏng nguy cơ xâm nhập mặn khu vực tỉnh Bà Rịa-Vũng Tàu đến năm 2050 theo các kịch bản biến đổi khí hậu RCP4.5 và $\mathrm{RCP} 8.5$. Kết quả cho thấy mặn có khả năng xâm nhập các huyện phía Nam, phân bố dọc theo sông Ray, sông Cỏ Mây và sông Dinh gần về phía hạ lưu. 
Về độ mặn max: đến năm 2050, độ mặn cao nhất trên sông Dinh đoạn chảy qua tỉnh huyện Long Điền và Tp. Vũng Tàu không lớn $(<1 \%$ ), theo đó, biên độ dao động mặn không đáng kể. Trên sông Thị Vải, độ mặn ở vị trí ranh giới tỉnh khoảng 1,23\%o (RCP8.5).

Về phạm vi XNM: đến năm 2050, RM 1\%o trên sông Ray chưa xâm nhập vào địa phận huyện Châu Đức. Trong khi đó, trên sông Thị Vải, RM này vượt qua ranh giới tỉnh khoảng $2,7 \mathrm{~km}$ và $5,7 \mathrm{~km}$ tương ứng với $\mathrm{RCP} 4.5$ và $\mathrm{RCP} 8.5$. Huyện Tân Thành là khu vực đáng quan tâm nhất trong mối quan hệ với XNM, chiếm $68 \%$ diện tích phơi nhiễm với XNM cả tỉnh (> $1 \%$ ).

Tại cùng một thời điểm tính toán, kịch bản RCP4.5 và RCP8.5 cho kết quả mô phỏng XNM khu vực tỉnh Bà Rịa-Vũng Tàu khác nhau không đáng kể. Nguyên nhân do các sông chính nằm sâu trong nội đồng nên ít chịu ảnh hưởng của triều cường.

Nhìn chung, kết quả XNM theo các kịch bản có sai khác tương đối so với hiện trạng mặn năm 2018. Các kịch bản có mực nước biển dâng càng cao thì ranh mặn càng tiến sâu hơn vào thượng nguồn. Các vùng bị ảnh hưởng bởi độ mặn trên $10 \%$ vẫn là các vùng ven biển đặc biệt là hạ lưu sông Thị Vải, hạ lưu sông Rạng, hạ lưu sông Chà Và, hạ lưu sông Dinh, hạ lưu sông Cửa Lấp, hạ lưu sông Ray. Các vùng đất ven sông cũng có khả năng bị phơi nhiễm với độ mặn tương ứng trên sông.

Việc gia tăng XNM là do NBD ở khu vực các cửa sông và một phần lưu lượng đã giảm trong mùa khô do phục vụ nhu cầu phát triển kinh tế xã hội, như tưới tiêu nông nghiệp và các hoạt động khác trên địa bàn tỉnh. Hiện nay, mạng lưới quan trắc giám sát mặn trên địa bàn tỉnh còn hạn chế nên số liệu và các tài liệu liên quan về xâm nhập mặn của tỉnh BRVT chưa được đầy đủ; do đó đây cũng là những hạn chế của các kết quả nghiên cứu này.

Đóng góp của tác giả: Xây dựng ý tưởng nghiên cứu: N.V.H.; Lựa chọn phương pháp nghiên cứu: N.V.H., N.P.Đ.; Xử lý số liệu: N.P.Đ.; Viết bản thảo bài báo: N.V.H., N.P.Đ.; Chỉnh sửa bài báo: N.V.H., N.P.Đ.

Lời cảm ơn: Nghiên cứu này được thực hiện dưới sự tài trợ của dự án "Xây dựng kế hoạch hành động ứng phó với BĐKH giai đoạn 2020-2030, tầm nhìn 2050 cho tỉnh Bà Rịa Vũng Tàu”, Sở Tài Nguyên và Môi trường tỉnh Bà Rịa Vũng Tàu.

Lời cam đoan: Tập thể tác giả cam đoan bài báo này là công trình nghiên cứu của tập thể tác giả, chưa được công bố ở đâu, không được sao chép từ những nghiên cứu trước đây; không có sự tranh chấp lợi ích trong nhóm tác giả.

\section{Tài liệu tham khảo}

1. Dyer, K.R. Estuaries: a physical introduction. Wiley Press, 1973.

2. Thanh, B; My, N.T.T. Tác động của biến đổi khí hậu và đề xuất định hướng ứng phó đối với lĩnh vực tài nguyên nước, quy hoạch sử dụng đát, hạ tầng và chống ngập đô thị tại tỉnh Bà Rịa - Vũng Tàu. Tạp chí Khi tương Thủy Văn 2013, 12, 12-17.

3. UBND tỉnh Bà Rịa Vũng Tàu. Báo cáo kinh tế-xã hội tỉnh Bà Rịa Vũng Tàu, năm 2018, 2019.

4. Phân viện Khoa học Khí tượng Thủy văn và Biến đổi khí hậu. Xây dựng, cập nhật kế hoạch hành động ứng phó với Biến đổi khí hậu giai đoạn 2021-2030, tầm nhìn 2050. Sở TNMT Bà Rịa Vũng Tàu, 2020.

5. Phân viện Khoa học Khí tượng Thủy văn và Biến đổi khí hậu. Đánh giá khí hậu tỉnh Bà Rịa Vũng Tàu. Sở TNMT Bà Rịa Vũng Tàu, 2020.

6. Việt, L.V. Đặc điểm phân bố mưa Miền Đông Nam Bộ, Đề tài NCKH - Trung tâm KTTV Phía Nam, 1998.

7. Việt, L.V. Nghiên cứu sự biến động mưa, nhiệt, ẩm khu vực đồng bằng sông Cửu Long và khả năng dự báo. Đề tài nghiên cứu Cấp Bộ - Bộ Khoa học Công nghệ, 2006. 
8. Toàn, P.N.; Đắc, P.T. Khí hậu Việt Nam, Nhà xuất bản Khoa học và Kỹ Thuật, Hà Nội, 1991.

9. Minh, T.C. Khí hậu và khí tượng đại cương, Nhà xuất bản Đại học Quốc gia Hà Nôi, 2007.

10. Sở TNMT tỉnh Bà Rịa Vũng Tàu. Báo cáo Hiện trạng Môi trường tỉnh Bà Rịa Vũng Tàu năm 2018. BRVT, 2018.

11. DHI. User Manual, 2014.

12. Bộ Tài nguyên và Môi trường. Kịch bản Biến đổi Khí hậu, nước biển dâng cho Việt Nam. Nhà xuất bản Tài nguyên - Môi trường và Bản đồ Việt Nam, Hà Nội, 2009.

13. Bộ Tài nguyên và Môi trường. Kịch bản Biến đổi Khí hậu, nước biển dâng cho Việt Nam. Nhà xuất bản Tài nguyên - Môi trường và Bản đồ Việt Nam, Hà Nội, 2012.

14. Bộ Tài nguyên và Môi trường. Kịch bản Biến đổi khí hậu và nước biển dâng cho Việt Nam. Nhà xuất bản Tài nguyên - Môi trường và Bản đồ Việt Nam, 2016.

15. IPCC. Climate Change: The Scientific Basis. Contribution of Working Group I to the Fourth Assessment Report of the Intergovernmental Panel on Climate Change, Cambridge University Press, Cambridge, United Kingdom and New York, NY, USA. 2007.

16. IPCC Fifth Assessment Report: Climate Change 2013 - The Physical Science Basis. Cambridge University Press, Cambridge, UK, 2013, pp. 1535.

17. IPCC. The Physical Science Basis. Contribution of Working Group I to the Fourth Assessment Report of the Intergovernmental Panel on Climate Change, 2007.

18. IPCC. The Physical Science Basis. Contribution of Working Group I to the Fifth Assessment Report of the Intergovernmental Panel on Climate Change, 2013.

19. IPCC. Managing the Risks of Extreme Events and Disasters to Advance Climate Change Adaptation, A Special Report of Working Groups I and II of the Intergovernmental Panel on Climate Change, Cambridge University Press, 2012.

20. Kaergaard, K.; Fredsoe, J. Numerical modeling of shoreline undulations part 1: Constant wave climate. Coast. Eng. 2013, 75, 64-76.

\title{
Simulation of saline intrusion in main rivers of ba ria - vung tau province under the context of climate change
}

\author{
Nguyen Van Hong ${ }^{*}$, Nguyen Phuong Dong ${ }^{1}$ \\ ${ }^{1}$ Sub-Institute HydoMeteogology and Climate Change; nguyenvanhong79@gmail.com; \\ donghai930t110@gmail.com
}

\begin{abstract}
This paper focuses on simulating the danger of saline intrusion in the main rivers in Ba Ria-Vung Tau province for periods to 2050 according to climate change scenarios RCP4.5 and RCP8.5. In the study, using MIKE model with MIKE NAM module to calculate runoff from rain, as input condition to MIKE 11 module, continue to simulate hydraulic and saline intrusion. The results from the model show that the salinity concentration is mainly in the southern districts, distributed along Ray River, Co May River and Dinh River near downstream. Meanwhile, on Thi Vai River, this saline boundary crosses the provincial boundary by about $2.7 \mathrm{~km}$ and $5.7 \mathrm{~km}$ respectively with RCP4.5 and RCP8.5. The highest salinity on Dinh river, which flows through Long Dien district and Vung Tau city, is not high $(<1 \%)$, accordingly, the salinity fluctuation amplitude is not significant. Tan Thanh district is the area of most concern in relation to saline intrusion, accounting for $68 \%$ of the province's area exposed to saline intrusion $(>1 \%)$.
\end{abstract}

Keywords: Salinity intrusion; Climate change; Sea level rise; Scenarios. 